\title{
pH-profiles of cellulases depend on the substrate and architecture of the binding region
}

Røjel, Nanna; Kari, Jeppe; Sørensen, Trine Holst; Borch, Kim; Westh, Peter

\section{Published in:}

Biotechnology and Bioengineering

Link to article, DOI:

10.1002/bit.27206

Publication date:

2020

Document Version

Peer reviewed version

Link back to DTU Orbit

\section{Citation (APA):}

Røjel, N., Kari, J., Sørensen, T. H., Borch, K., \& Westh, P. (2020). pH-profiles of cellulases depend on the substrate and architecture of the binding region. Biotechnology and Bioengineering, 117(2), 382-391. https://doi.org/10.1002/bit.27206

\section{General rights}

Copyright and moral rights for the publications made accessible in the public portal are retained by the authors and/or other copyright owners and it is a condition of accessing publications that users recognise and abide by the legal requirements associated with these rights.

- Users may download and print one copy of any publication from the public portal for the purpose of private study or research.

- You may not further distribute the material or use it for any profit-making activity or commercial gain

- You may freely distribute the URL identifying the publication in the public portal 


\section{(2) Promega}

\section{Don't settle for just a}

supplier. Find a custom manufacturing partner.

\section{Your specifications. Your format.}

\section{Our scientists waiting to help.}

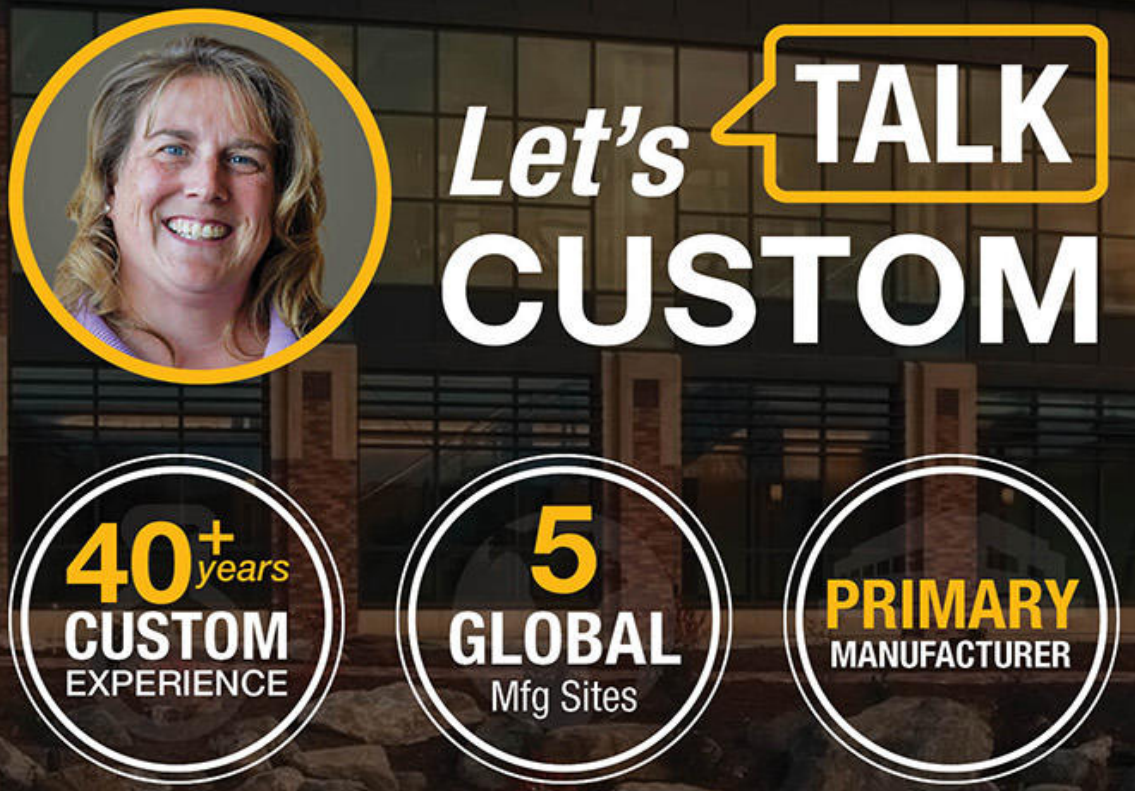

Selecting a supplier for your biotechnology and biopharma products can be a challenge-especially one who can adapt to your specific needs. Don't settle for just a supplier. Instead, partner with Promega and work with a custom manufacturer willing to provide you with the scientific expertise, ongoing technical support and quality standards that support your success.

Learn more with our video:
promega.com/CustomProcess 
Nanna Røjel ORCID iD: 0000-0003-2887-3738

Peter Westh ORCID iD: 0000-0002-6185-0637

\title{
pH-profiles of cellulases depend on the substrate and architecture of the binding region.
}

\author{
Nanna Røjel ${ }^{1 \#}$, Jeppe Kari ${ }^{1,2}$, Trine Holst Sørensen ${ }^{3}$, Kim Borch $^{3}$ \& Peter Westh ${ }^{2 \dagger}$ \\ ${ }^{1}$ Roskilde University, INM, 1 Universitetsvej, Building 28, DK-4000, Roskilde, Denmark \\ ${ }^{2}$ Technical University of Denmark, Department of Biotechnology and Biomedicine. Building \\ 224, DK-2800, Kgs. Lyngby, Denmark \\ ${ }^{3}$ Novozymes A/S, Krogshøjvej 36, DK-2880 Bagsværd, Denmark \\ \#Present address: Technical University of Denmark, Department of Biotechnology and \\ Biomedicine. Building 224, DK-2800, Kgs. Lyngby, Denmark \\ †Corresponding author. Email: petwe@dtu.dk Tel. +45 45252641 or +45 30915488 \\ Grant number: This work was supported by Novo Nordisk Foundation, Innovation Fund \\ Denmark [Grant number: 5150-00020B to P.W.] and Carlsberg Foundation [Grant number: 2013- \\ 01-0208].
}

\begin{abstract}
Understanding pH effect of cellulolytic enzymes are of great technological importance. In this study, we have examined the influence of $\mathrm{pH}$ on activity and stability for central

This article has been accepted for publication and undergone full peer review but has not been through the copyediting, typesetting, pagination and proofreading process, which may lead to differences between this version and the Version of Record. Please cite this article as doi: 10.1002/bit.27206.
\end{abstract}

This article is protected by copyright. All rights reserved. 
cellulases (Cel7A, Cel7B, Cel6A from Trichoderma reesei and Cel7A from Rasamsonia emersonii). We systematically changed $\mathrm{pH}$ from 2 to 7 , temperature from $20-70^{\circ} \mathrm{C}$, and used both soluble (pNPL) and insoluble (Avicel) substrates at different concentrations. Collective interpretation of these data provided new insights. An unusual tolerance to acidic conditions was observed for both investigated Cel7As, but only on real insoluble cellulose. In contrast, pH-profiles on pNPL were bell-shaped with strong loss of activity both above and below the optimal $\mathrm{pH}$ for all four enzymes. On a practical level, these observations calls for caution of the common practice of using soluble substrates for general characterization of $\mathrm{pH}$ effects on cellulase activity. Kinetic modeling of the experimental data suggested that the nucleophile of Cel7A experiences a strong downward shift in $\mathrm{pK}_{\mathrm{a}}$ upon complexation with an insoluble substrate. This shift was less pronounced for Cel7B, Cel6A and for Cel7A acting on soluble substrate, and we hypothesize that these differences are related to the accessibility of water to the binding region of the Michaelis complex.

Key words (3-5): $\mathrm{pH}$, temperature, cellobiohydrolase, endoglucanse, cellulose

\section{Introduction}

Elucidation of relationships between $\mathrm{pH}$, temperature and activity makes up an indispensable part of the characterization of any enzyme considered for an industrial application. This is also true for cellulases, which are of immediate commercial interest because they are used for the conversion of lignocellulosic biomass to fermentable sugars. This so-called enzymatic saccharification is a critical process step in planned biorefineries, and its sensitivity to $\mathrm{pH}$ is of particular interest because some methods for

This article is protected by copyright. All rights reserved. 
biomass pretreatment involves either acidic or alkaline conditions (Mosier et al., 2005). This leads to considerations regarding strategies for neutralization and potential $\mathrm{pH}$ drift during saccharification and assessment of these questions obviously requires knowledge of how sensitive the enzymatic process is to changes in $\mathrm{pH}$. Clarification of $\mathrm{pH}$ effects on saccharification will require both extensive empirical work under process relevant conditions and a better fundamental understanding of the enzymatic process. Progress in the former area was recently achieved as Herlet et al. (2017) introduced an effective methodology for screening $\mathrm{pH}$ and temperature effects on saccharification. In the current work, we address the latter and report systematic measurements of activity and stability of selected (monocomponent) cellulases, as a function of $\mathrm{pH}$, temperature as well as the type and load of substrate.

Cellulases hydrolyze the $\beta-1,4$ glucosidic bond between the glycopyranose moieties in cellulose. The enzymatic reaction occurs in the heterogeneous environment of the cellulose-water interface, and involves multifaceted interactions including both binding of the polymeric substrate to an extended active site region and attractive forces between the other parts of the enzyme and the surface of the insoluble substrate (Divne, Ståhlberg, Teeri, \& Jones, 1998; Linder \& Teeri, 1997; Payne et al., 2013). This complex mode of action on the real insoluble substrate is associated with a quite intricate kinetic behavior that is still only partially understood (Bansal, Hall, Realff, Lee, \& Bommarius, 2009). Perhaps for that reason, cellulases are often characterized on soluble substrate analogs that are convenient to work with and provide results, which can be readily rationalized by conventional enzyme kinetic theory. The use of soluble substrate has been particularly dominant in $\mathrm{pH}$ studies, and many works have reported traditional bell-shaped $\mathrm{pH}$

This article is protected by copyright. All rights reserved. 
profiles with an apex (i.e. optimal pH value) around pH 4-5 (see e.g. (Becker et al., 2001;

Boer \& Koivula, 2003; Borisova et al., 2018; Hobdey et al., 2016; Momeni et al., 2013; Schülein, 1997)). Work with soluble substrate has also identified cellulase wild-types with higher (Cockburn, Vandenende, \& Clarke, 2010) or lower (Pellegrini et al., 2015; Texier, Dumon, Neugnot-Roux, Maestracci, \& O'Donohue, 2012) pH optima, and engineered enzyme variants with upwards shifts of the optimal value (Becker et al., 2001; Cockburn et al., 2010; Qin, Wei, Song, \& Qu, 2008). Some studies have addressed the pH-activity profiles of cellulases acting on pure cellulose (Borisova et al., 2015; Colussi et al., 2012; Marjamaa, Toth, Bromann, Szakacs, \& Kruus, 2013; Ogunmolu et al., 2017), and while differences between $\mathrm{pH}$ profiles on soluble and insoluble substrates have been identified, no systematic picture has emerged. This could, at least in part, be because most of these $\mathrm{pH}$ profiles are based on measurements at a single load of cellulose, although this is known to limit interpretations of pH-activity relationship (Knowles \& Jencks, 1976). We conclude that there is no clear picture of whether $\mathrm{pH}$ profiles of cellulases depends on the nature of the substrate, and in the light of the distinctive effect of the substrate on kinetic parameters (Becker et al., 2001; Borisova et al., 2018; Hobdey et al., 2016; Sørensen et al., 2015), systematic work on pH effects appears warranted. To address this, we measured $\mathrm{pH}$ profiles for selected cellulases over different ranges of temperature and substrate loads for both soluble and insoluble substrates. We chose Avicel as a model for insoluble cellulose, primarily because this is the most widely used substrate and hence the best outset for comparative analyses. Avicel is prepared from wood pulp by dilute hydrochloric acid treatment, contains comparable amounts of crystalline and amorphous material and has low accessible surface area compared to other

This article is protected by copyright. All rights reserved. 
model substrates (Zhang \& Lynd, 2004). Our results showed conspicuous differences between soluble and insoluble substrates and identified an extreme tolerance to acidic conditions for some cellulases under saturating substrate loads.

\section{Material and methods}

Enzyme, substrate and buffers. The enzymes Cel7A, Cel7B, Cel6A from Trichoderma reesei (henceforth abbreviated TrCel7A, TrCel7B, TrCel6A) and Cel7A from Rasamsonia emersonii (ReCel7A) were expressed in and purified Aspergillus oryzae as described previously (Borch et al., 2014; Sørensen et al., 2015). The three T. reesei enzymes consists of a catalytic domain and a Family 1 Carbohydrate Binding Domain (CBM) connected with a flexible peptide linker. Conversely, ReCel7A is only a catalytic domain without CBM and linker. Enzyme purity was verified by SDS-PAGE, which showed only one band (data not shown), and concentrations were measured by UV absorption at $280 \mathrm{~nm}$. We used calculated extinction coefficients (Pace, Vajdos, Fee, Grimsley, \& Gray, 1995) for TrCel7A $\left(86760 \mathrm{M}^{-1} \mathrm{~cm}^{-1}\right)$, TrCel7B $\left(74145 \mathrm{M}^{-1} \mathrm{~cm}^{-1}\right)$, TrCel6A $\left(97790 \mathrm{M}^{-1} \mathrm{~cm}^{-1}\right)$ and ReCel7A $\left(74925 \mathrm{M}^{-1} \mathrm{~cm}^{-1}\right)$. The microcrystalline substrate (Avicel PH101, Sigma-Aldrich, product no. 11365), was washed seven times in Milli-Q water to remove any soluble compounds. To enable activity and stability measurements at different $\mathrm{pH}$ (but otherwise similar conditions) we prepared mixed buffers of citrate and phosphate (so-called Mcllvaine buffer). This system is expedient due to its wide buffer range and low temperature dependence (Herlet et al., 2017). Eleven solutions with $\mathrm{pH}$ 2-7 were made with $0.5 \mathrm{pH}$ units interval by mixing $0.1 \mathrm{M}$ citric acid (VWR chemicals product no. 20273.292) and $0.2 \mathrm{M}$ di-sodium hydrogen phosphate $\mathrm{Na}_{2} \mathrm{HPO}_{4}$ (Merck, Darmstadt, product no. 1.06580) in appropriate ratios. The effect of temperature 
was tested by measuring $\mathrm{pH}$ at $25^{\circ} \mathrm{C}, 40^{\circ} \mathrm{C}$ and $60{ }^{\circ} \mathrm{C}$ for all Mcllvaine buffer mixtures. Prior to these measurements, the $\mathrm{pH}$-meter was calibrated with three certified buffer standard solutions (Hach, Loveland, $\mathrm{CO}$ ) at the relevant temperature (using the nominal $\mathrm{pH}$-value of the certified standard solution at the experimental temperature provided by the manufacturer). This procedure showed that the $\mathrm{pH}$ value of the McIlvaine buffer mixtures changed negligibly with temperature over the interval used here. Work with this system inevitably leads to buffers with different absolute concentrations (and hence ionic strength) as the two stocks have different concentrations. To test possible effects of this, we measured the activity of all four enzymes on Avicel at $\mathrm{pH} 4.5$ in buffers with the same mixing ratio, but different absolute concentrations (using different buffer stock concentrations). Results in the Supplementary Information Fig S1 showed that the activity was only marginally affected by the buffer concentration in the relevant range, and we will therefore neglect such effect in the following discussion.

Avicel assay. We investigated the reaction at two different Avicel loads; $1 \mathrm{~g} / \mathrm{L}$ and 90 g/L. In both cases, the substrates suspensions were prepared by 1:1 (vol/vol) mixing of Avicel in MQ-water and the relevant McIlvaine buffer mixture in 96-well microtiter plates (96F 269620, Thermo Scientific). The final buffer concentration ranged between 50 and $100 \mathrm{mM}$. To start the hydrolysis, $20 \mu \mathrm{L}$ enzyme was added to a final concentration of $100 \mathrm{nM}$ for TrCel7A, TrCel6A and ReCel7A and $25 \mathrm{nM}$ for TrCel7B as preliminary measurements had shown higher activity of this latter enzyme. This was confirmed in Fig. 1, where the specific activity of TrCel7B was about 5-fold higher compared to TrCel7A in the temperature range where both enzymes were stable (at the highest investigated temperatures, this advantage of TrCel7B vanished due to poor

This article is protected by copyright. All rights reserved. 
thermostability). In terms of mass ratios, the enzyme dosages range from about $0.013 \mathrm{mg}$ enzyme/g cellulose for Cel7B acting on $90 \mathrm{~g} / \mathrm{L}$ Avicel to about $5.2 \mathrm{mg}$ enzyme/g cellulose for TrCel7A acting on $1 \mathrm{~g} / \mathrm{L}$ Avicel. To limit interference from reducing groups on either enzymes or soluble fragments from the cellulose, we included blanks for both enzyme and Avicel.

The plates were pre-equilibrated at the desired temperature before adding the enzyme, and sealed immediately after. They were then mixed at $1.100 \mathrm{rpm}$ in an Eppendorf Thermomixer with ThermoTop for $60 \mathrm{~min}$. This procedure was repeated at temperatures from $20{ }^{\circ} \mathrm{C}$ to $70{ }^{\circ} \mathrm{C}$ with a $10{ }^{\circ} \mathrm{C}$ interval. To stop the reaction, Avicel was separated from the supernatant by centrifugation of the plates at $2.000 \mathrm{~g}$ for $3 \mathrm{~min}$. All quantification of enzyme activity on Avicel was based on the 4-hydroxybenzhydrazide (PABAH) reducing end assay (Lever, 1973). Specifically, $75 \mu \mathrm{L}$ supernatant was transferred to a PCR plate and added $75 \mu \mathrm{L}, 15 \mathrm{mg} / \mathrm{mL}$ 4-hydroxybenzhydrazide (PAHBAH) dissolved in 0.18 M potassium sodium tartrate (Sigma, P2347) buffer with 0.5 M sodium hydroxide (Merck, 1.06469). The PCR plates were placed in a T100 ${ }^{\mathrm{TM}}$ PCR cycler (BioRad laboratories), at $95{ }^{\circ} \mathrm{C}$ for 10 min and cooled to $5{ }^{\circ} \mathrm{C}$ before being removed from the PCR cycler. Solutions for a six-point standard curve between 0-500 $\mu \mathrm{M}$ cellobiose (Fluka, 22150) were included in each plate. One-hundred $\mu \mathrm{L}$ solution from each well was transferred into 96-well microtiter plate, and the absorbance at 405 nm was determined by a plate reader (SpectraMax M2e, Molecular Devices). All samples and standards were measured in triplicates.

pNPL assay. Activity of TrCel7A, TrCel7B and ReCel7A on either $0.2 \mathrm{mM}$ or $9.0 \mathrm{mM} 4-$ nitrophenyl $\beta$-D-lactopyranoside (pNPL) (Sigma, N1752) was measured in triplicates at

This article is protected by copyright. All rights reserved. 
the previously mentioned $\mathrm{pH}$ values between 2 and 7, using the same buffers concentration as described above. The buffer and substrate were preheated to $30{ }^{\circ} \mathrm{C}$ for $10 \mathrm{~min}$ in an Eppendorf Thermomixer operating at $750 \mathrm{rpm}$ and the reaction was started by addition of enzyme to a final concentration of $0.5 \mu \mathrm{M}$ for TrCel7A, TrCel6A and ReCel7A, and $0.2 \mu \mathrm{M}$ for TrCel7B. The reaction was quenched after 15 min by adding 0.5 M glycine (1.04201 Merck) solution pH 10 to a final concentration of 0.2 M. Finally, conversion was assessed by the absorbance at $405 \mathrm{~nm}$ again using the SpectraMax plate reader.

Stability. Thermal stability was assessed by differential scanning fluorimetry (DSF) using a Prometeus NT.48 instrument (NanoTemper, Munich). All samples were scanned from $20^{\circ} \mathrm{C}-90^{\circ} \mathrm{C}$ at a rate of $2.0^{\circ} \mathrm{C} / \mathrm{min}$, and the transition temperature $\left(\mathrm{T}_{\mathrm{m}}\right)$ was determined both with and without substrate (Avicel). To measure $\mathrm{T}_{\mathrm{m}}$ with substrate, we used a protocol, which was similar to the activity measurements. Specifically, samples with 1 $\mu \mathrm{M}$ of enzyme and $90 \mathrm{~g} / \mathrm{L}$ Avicel (final concentrations) were mixed at all $\mathrm{pH}$ values and allowed to equilibrate for $20 \mathrm{~min}$ before the DSF measurements. Samples without substrate were prepared in the same way except that the Avicel suspension was replaced by MQ water. To minimize effects of Avicel precipitation, the samples were stirred at $1.100 \mathrm{rpm}$ in a thermomixer while loaded into capillary tubes for the DSF. All samples were run in duplicates, and the raw data was analyzed using the software that comes with the DSF instrument (P R ThermControl v 2.0.4, NanoTemper).

Plots. All graphs were made with Origin 2018 (OriginLab, Northampton, MA, USA), and structural pictures were prepared in the PyMOL Molecular Graphics System, Version 2.0 Schrödinger, LLC.

This article is protected by copyright. All rights reserved. 


\section{Results}

Figure 1 shows representative data from the activity and stability measurements (more data can be found in the Supporting information). Panel A-D illustrates how $\mathrm{pH}$ and temperature affects the specific activity of the four investigated enzymes at high substrate load (90 g Avicel/L). The specific activity was calculated as $\Delta \mathrm{C}_{\text {red ends }} / 3600 \mathrm{~s} / \mathrm{E}_{0}$, where $\Delta \mathrm{C}_{\text {red ends }}$ is the concentration of reducing ends produced in the $1 \mathrm{~h}$ trials and $\mathrm{E}_{0}$ is the enzyme concentration. Analogous results for low loads of Avicel (1 g/L) may be found in the Supporting information, S2. At the higher investigated temperatures, we consistently found bell shaped activity-pH profiles for all investigated enzymes. At lower temperatures, we also found bell-shaped curves for Cel7B and Cel6A, but not for TrCel7A and ReCel7A. However, the low-temperature behavior is difficult to single out in Fig. 1, and we will return to this below. Figure 1 (Panel E-G) also illustrates how the thermal stability ( $\mathrm{T}_{\mathrm{m}}$, measured by DSF) depend on $\mathrm{pH}$ without or with substrate (also 90 g/L Avicel). These results show that all four enzymes had optimal stability between $\mathrm{pH} 4$ and 5, where $\mathrm{T}_{\mathrm{m}}$ ranged from $76^{\circ} \mathrm{C}$ for ReCel7A to about $66^{\circ} \mathrm{C}$ for all three enzymes from T. reesei (TrCel7A, TrCel7B and TrCel6A). The results also clearly show that binding to the substrate promotes the thermal stability, as $\mathrm{T}_{\mathrm{m}}$ was consistently increased in the samples with Avicel (filled squares) compared to enzyme in pure buffer (open squares). For reversible thermal transitions, this shift in $\mathrm{T}_{\mathrm{m}}$ may be directly related to the enzyme-ligand binding constant, but as the current systems typically show irreversible transitions (Alasepp et al., 2014), the shifts between the two curves in Panels E-H only provides an apparent measure of binding strength. Nevertheless, we note that the shift depends only weakly on $\mathrm{pH}$ for all enzymes, thus suggesting that the strength of ligand 
binding is not strongly affected by $\mathrm{pH}$. We also note that the ReCel7A (Panel F), which does not have a carbohydrate binding module (CBM) shows a smaller shift than the other enzymes, which all have a CBM attached to the catalytic domain.

In the current context, the most important implication of the $T_{m}$ data in Fig. 1 is that it allows us to distinguish effects of $\mathrm{pH}$ on respectively catalytic efficacy and stability. If, for example, we consider TrCel7A, we can see that the strong loss in activity around $\mathrm{pH}$ 2-3 at $60{ }^{\circ} \mathrm{C}-70{ }^{\circ} \mathrm{C}$ (red and orange traces in panel A) are most likely caused by enzyme instability, as $T_{m}$ under these conditions hovers around or below the experimental temperature ( $\mathrm{T}_{\mathrm{m}}$ is 50 to $60{ }^{\circ} \mathrm{C}$, see Panel E). Conversely, the reduction in activity at 20 ${ }^{\circ} \mathrm{C}-40{ }^{\circ} \mathrm{C}$ and $\mathrm{pH}$ 5-6 for TrCel7B (panel G) is probably not related to instability as $\mathrm{T}_{\mathrm{m}}$ is much higher under these conditions. Inspection of the activity data in Fig. 1 (and Fig S2 of the Supplementary information) allowed us to assess possible interference from product (cellobiose) inhibition. If we consider TrCel7A at room temperature, the final cellobiose concentration at the optimal $\mathrm{pH}$ was around $0.07 \mathrm{mM}$ and this is $1-2$ orders of magnitude lower that typically reported inhibition constants, which fall in the 0.5-15 mM range depending on the experimental approach and substrate (Gruno, Väljamäe, Pettersson, \& Johansson, 2004; Murphy et al., 2013; Olsen et al., 2016; Teugjas \& Väljamäe, 2013). Product inhibition of Cel7A decreases rapidly at higher temperatures (Teugjas \& Väljamäe, 2013), and it is hence likely also to be negligible above room temperature. Finally, we note that the other investigated enzymes are only weakly inhibited by cellobiose (Murphy et al., 2013). This collectively suggests that effects of product inhibition will be marginal under the current conditions.

This article is protected by copyright. All rights reserved. 
We also investigated $\mathrm{pH}$-activity relationships for a soluble substrate analog (pNPL). We note that $\operatorname{TrCel6A}$, which attacks the non-reducing end of cellulose, has essentially no activity against pNPL (or any other reducing-end labeled substrate analog), and the work with soluble substrate was consequently limited to TrCel7A, TrCel7B and ReCel7A. These measurements at $30{ }^{\circ} \mathrm{C}$ included both high $(9 \mathrm{mM})$ and low $(0.2 \mathrm{mM})$ substrate concentrations. Results in Fig. 2 show traditional bell-shaped courses and based on the $T_{m}$ data in Fig.1 it seems safe to conclude that these results are unaffected by enzyme instability.

Figure 1

Figure 2

\section{Discussion}

Many hydrolytic enzymes, including the ones studied here, use two acid side chains - one protonated and one deprotonated - in their catalytic mechanism. Changes in the protonation status of the catalytic residues strongly reduces the catalytic efficacy and may explain the characteristic bell-shaped $\mathrm{pH}$-activity curves, which have been reported for many enzymes (Harris \& Turner, 2002). However, enzyme instability at suboptimal pH values may exert an additional (indirect) effect on $\mathrm{pH}$-activity profiles, and this makes it hard to interpret the effect of $\mathrm{pH}$ on an enzyme reaction without measuring both activity and stability under the same conditions. The results in Fig. 1 provides several examples of this. At the higher investigated temperatures, for example, we consistently found the characteristic bell shape of the activity curves (Panels A-D), but comparisons with the stability data (Panels E-H) clearly showed that this correlated with instability at the

This article is protected by copyright. All rights reserved. 
high/low end of the pH range. Thus, all the cellulases showed a marked decrease of 18-25 ${ }^{\circ} \mathrm{C}$ in $\mathrm{T}_{\mathrm{m}}$ between the optimal stability value at $\mathrm{pH} 4.5$ (for all four enzymes) and $\mathrm{pH}$ 2.0. In practice, this meant that at the highest experimental temperatures, the enzymes were marginally stable near $\mathrm{pH} 4.5$, but unstable (experimental temperature near or higher than $\mathrm{T}_{\mathrm{m}}$ ) at higher or lower $\mathrm{pH}$ values and this is suggested to underlie the bell-shaped activity profiles at high temperatures in Fig.1. This effect of $\mathrm{pH}$ on enzyme stability is clearly relevant for technical applications of cellulases, which often involves high temperature, but it is not the focus of the current discussion. Instead, we will center on $\mathrm{pH}$-activity relationships under conditions where the enzyme is stable, and primarily use the stability data in Fig. 1 to identify conditions where instability can be neglected.

One conspicuous observation for Avicel hydrolysis in the stable temperature range (20 $40{ }^{\circ} \mathrm{C}$ ) is that the activity profiles for the two Cel7A enzymes (TrCel7A and ReCel7A) are not bell shaped. To illustrate this more clearly, we converted the specific activities in Fig. 1 into relative values by normalizing with the maximal activity at $\mathrm{pH} 4.5$. Results at $40{ }^{\circ} \mathrm{C}$ are plotted for all four enzymes in Fig. 3, and it appears that the two Cel7As retain a constant activity throughout the low $\mathrm{pH}$ range covered here. For TrCel7A, which had the broadest plateau in Fig. 3, we could not detect any changes in activity between $\mathrm{pH} 2$ and $\mathrm{pH}$ 5.5. For TrCel6A and TrCel7B, on the other hand, we found bell-shaped curves with strongly reduced activity below $\mathrm{pH} 4.5$ (this part of the bell-shaped curve is sometimes called the acidic limb of the $\mathrm{pH}$ profile). We found analog behavior at lower temperatures, and for the thermostable ReCel7A (Voutilainen, Murray, Tuohy, \& Koivula, 2010), which had a $\mathrm{T}_{\mathrm{m}}$ well above $50^{\circ} \mathrm{C}$ throughout the $\mathrm{pH}$ range (Fig. 1F) we also found the plateau at low $\mathrm{pH}$ at this temperature (see Fig. 1 panel B).

This article is protected by copyright. All rights reserved. 


\section{Figure 3}

Earlier investigations of Cel7A's pH profile have mostly used soluble substrate analogs (see Introduction), and like the current work on pNPL (Fig. 2) they have all found the characteristic slope of the acidic limb of the profile. Some earlier studies have reported pH profiles for fungal Cel7As based on activity measurements on Avicel (Colussi et al., 2012; Marjamaa et al., 2013; Ogunmolu et al., 2017). Unlike the results in Fig. 3, however, these reports found sloping acidic limbs although the slope was quite shallow except in one case (Ogunmolu et al., 2017). These previous profiles on Avicel were all made at low substrate loads (5-10 g/L), and to test possible effects of this, we repeated the measurements at $40{ }^{\circ} \mathrm{C}$ with very low load $(1 \mathrm{~g} / \mathrm{L})$. Results in the Supporting information, S2, reveal that the acidic limb of both Cel7As indeed showed the typical slope, when assayed at a low load. To evaluate this effect of substrate load, we note that at room temperature and $\mathrm{pH}$, the Michaelis constants, $\mathrm{K}_{\mathrm{M}}$, on Avicel for the two Cel7As investigated here are in the 5-10 g/L range (Sørensen et al., 2015; Sørensen et al., 2017). This was confirmed experimentally in the current work through analysis of Michaelis-Menten curves at different $\mathrm{pH}$ and temperature (see Supplementary Material, Fig. S3). This data also documented that $\mathrm{K}_{\mathrm{M}}$ did not increase significantly over the $\mathrm{pH}-$ range studied here, and thus, it appears that the extreme tolerance to low $\mathrm{pH}$ for the two Cel7As occurs when essentially all enzyme was complexed. Conversely, the two other enzymes (TrCel6A and TrCel7B) as well as the two Cel7As under conditions (low substrate load) where most enzyme is free showed the typical slope of the acidic limb. To assess these differences further, we examined the structures of the enzyme-substrate complexes (Grassick et al., 2004; Kleywegt et al., 1997; Knott et al., 2014; Zou et al., 
1999). One view of these structures is shown in Fig. 3b, and reiterates (Bu et al., 2012;

Taylor et al., 2013) that there are strong differences in the openness of the substratebinding cleft among these enzymes. TrCel7A, for example, has eight peripheral loops that essentially covers the cleft to form a tunnel-shaped binding region (Knott et al., 2014). Similarly, ReCel7A has eight loops (Grassick et al., 2004), although a truncation of the so-called A1 loop (Momeni et al., 2013) makes the cleft marginally more open compared to TrCel7A. The endolytic TrCel7B, has four smaller loops (Kleywegt et al., 1997) resulting in an open binding cleft with easy access. Finally, TrCel6A has two large active-site loops (Zou et al., 1999), which makes up a shorter tunnel that covers a smaller section of the ligand compared to the two Cel7As, but it is less open to solvent than TrCel7B. It is interesting to note that the slopes of the acidic limbs in Fig. 3 seems to follow the same order as the openness of the enzymes' binding clefts (enzymes with more open clefts are more inhibited by low $\mathrm{pH}$ ). Molecular interpretations of this remain elusive, but it could rely on the accessibility of water to bound ligand or the number of ligand contacts in the Michaelis complex which have both been shown to scale with coverage of the binding cleft (Taylor et al., 2013). These latter parameters also appears to be relavant for the observed effects of substrate concentration. To illustrate this, we converted the absolute activities of Cel7A against respectively Avicel (data from Fig. 1) and pNPL (data from Fig. 2) to relative values. We used the activity at $30^{\circ} \mathrm{C}$ and $\mathrm{pH} 4.5$ as reference and plotted relative activities of Cel7A at $30^{\circ} \mathrm{C}$ against $\mathrm{pH}$ in Fig. 4. To highlight a possible relationship to water accessibility we included both high and low substrate loads of both substrates. The results in Fig. 4 show that higher loads of both substrates promote activity in the acidic range. In other words, Cel7A was generally more

This article is protected by copyright. All rights reserved. 
tolerant to low $\mathrm{pH}$, when the substrate was plentiful and most enzyme was engaged in a complex ( $\mathrm{K}_{\mathrm{M}}$ for Cel7A acting on pNPL is around $2 \mathrm{mM}$ (Hobdey et al., 2016; Sørensen et al., 2017)). Figure 4 also underscores that binding of a cellulose strand that fills the entire substrate binding tunnel, brings about higher tolerance to low $\mathrm{pH}$ compared to binding of a small substrate analog, which only cover a small part of the tunnel (Jalak \& Väljamäe, 2010). Taken together, the results in Fig. 4 support a relationship between water in the binding tunnel and the effect of acid on activity. These qualitative arguments may be further evaluated by modeling the experimental data, and we will do so in the next section.

Figure 4

Modeling $\mathrm{pH}$ profiles. We applied a well-established approach (Alberty \& Bloomfield, 1963) to model effects of $\mathrm{pH}$. Specifically, we used a version, where the enzyme is described as a diprotic acid and catalysis is assumed to occur only when one acid is protonated and the other is not (Marangoni, 2003). This can be expressed as in Scheme (1). We note that this approach was developed for soluble enzyme-substrate systems, but as argued elsewhere (Andersen, Kari, Borch, \& Westh, 2018; Kari, Andersen, Borch, \& Westh, 2017), an analogous treatment may be permissible for interfacial reactions provided that the usual requirement of substrate excess is fulfilled.

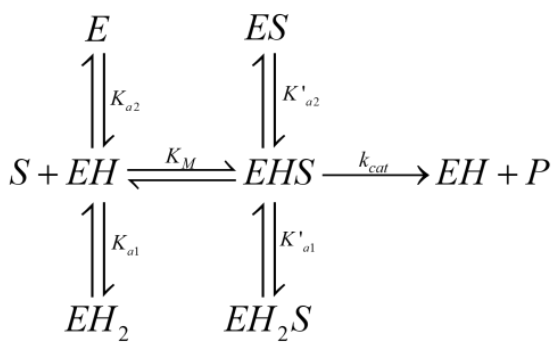

This article is protected by copyright. All rights reserved. 
Here, $K_{a 1}$ and $K_{a 2}$ are the two acid constants in the apoprotein while $\mathrm{K}_{\mathrm{a} 1}^{\prime}$ and $\mathrm{K}_{\mathrm{a} 2}^{\prime}$ are the acid constants in the enzyme-substrate complex. Advantages and limitations of this approach has been widely discussed (Knowles \& Jencks, 1976; Marangoni, 2003), and we will not repeat these arguments here.

Rate equations for Scheme (1) can be readily derived under the rapid equilibrium approximation (Marangoni, 2003), and it is generally useful to consider two limiting cases in which either $\mathrm{S}_{0}<<\mathrm{K}_{\mathrm{M}}$ or $\mathrm{S}_{0}>>\mathrm{K}_{\mathrm{M}}$. Under these conditions, the enzyme is predominantly in the free state or in the Michaelis complex, respectively. The apo-forms $\mathrm{E}, \mathrm{EH}$ and $\mathrm{EH}_{2}$ will dominate in the limiting case where $\mathrm{S}_{0}<<\mathrm{K}_{\mathrm{M}}$, and hence modeling under these conditions will return $\mathrm{K}_{\mathrm{a}}$ values of the apoprotein $\left(\mathrm{K}_{\mathrm{a} 1}\right.$ and $\left.\mathrm{K}_{\mathrm{a} 2}\right)$. Conversely, modeling at high substrate load where ES, EHS and $\mathrm{EH}_{2} \mathrm{~S}$ dominate will elucidate $\mathrm{K}_{\mathrm{a} 1}{ }^{\prime}$ and $\mathrm{K}_{\mathrm{a} 2}^{\prime}$. As already stated, the high/low values of substrate loads are well above/below $\mathrm{K}_{\mathrm{M}}$ for both Avicel and pNPL, and the data therefore reasonably represent the limiting cases. This interpretation is further supported by published binding parameters for the same enzyme-substrate systems (Badino, Kari, Christensen, Borch, \& Westh, 2017; Schiano-di-Cola et al., 2019; Westh et al., 2018), which suggests almost complete adsorption of enzyme (85-98\% bound) at high Avicel load (90 g/L). We used non-linear regression analyses to fit the $\mathrm{pH}$ curves as detailed in the Supporting information. The model accounted well for the experimental data except in the case of low Avicel load (1 $\mathrm{g} / \mathrm{L}$ ), where the experimental data had too much noise to sustain proper modeling (Sup. Mat, Fig S2). The $\mathrm{pK}_{\mathrm{a}}$ values derived from modeling the remainder of the data are listed in Tabs. 1 and 2 (see fitted data in Supp. Info Fig. S4 and S5).

Table 1 : Table 2

This article is protected by copyright. All rights reserved. 
As argued above, $\mathrm{pK}_{\mathrm{a}}$ values obtained from measurements at very low $\mathrm{pNPL}$ concentrations may be taken as representative of the apoenzyme, and values in Tab. 1 are in line with earlier suggestions based on experimental (Becker et al., 2001) and computational (Bu, Crowley, Himmel, \& Beckham, 2013) studies. For Cel7A, these earlier works assigned the low $\mathrm{pK}_{\mathrm{a}}$ value $\left(\mathrm{pK}_{\mathrm{a} 1}\right.$ in Tab. 1) to the nucleophile in the catalytic reaction (Glu212 in TrCel7A numbering), while the higher $\mathrm{pK}_{\mathrm{a}}\left(\mathrm{pK}_{\mathrm{a} 2}\right)$ was assigned to the catalytic acid/base, Glu217. If we use the same assignments and compare results at low and high substrate concentration in Tab. 1, we find that binding of pNPL to TrCel7A imparts a downwards $\mathrm{pK}_{\mathrm{a}}$ shift of over 1 unit (from $\mathrm{pK}_{\mathrm{a} 1}=2.7$ to $\mathrm{pK}_{\mathrm{a} 1}^{\prime}=1.6$, Tab. 1). Somewhat smaller shifts of $\mathrm{pK}_{\mathrm{a} 1}$ (in the same direction) are seen for the other two enzymes in Tab. 1, and considering the similarity among these Cel7 enzymes, it appears reasonable to conclude that this also reflects changes in $\mathrm{pK}_{\mathrm{a}}$ of the nucleophile. More importantly, comparisons of $\mathrm{pK}_{\mathrm{a}}$ values in the apoenzyme (Tab 1, low pNPL) and cellulose bound enzyme (Tab 2) suggests that the nucleophile in the two Cel7As experience a pronounced downward shift upon binding to the natural substrate. This shift is much lower for Cel7B binding cellulose, and for the binding of a small substrate analog to Cel7A, and this may again suggest a linkage to the degree of dehydration of the binding cleft when the Michaelis complex is formed. The extent of the $\mathrm{pK}_{\mathrm{a}}$-shift for the Cel7As upon cellulose binding cannot be established precisely because $\mathrm{pK}^{\prime}{ }_{\mathrm{a} 1}$ is too low to be modelled from data in the current $\mathrm{pH}$ range ( $\mathrm{pH}$ 2-7). It would require still lower experimental $\mathrm{pH}$ values to assess $\mathrm{pK}^{\prime}{ }_{\mathrm{a} 1}$, however, with the level of experimental scatter in Fig. 3, a decrease in activity would be detectable if $\mathrm{pK}^{\prime}{ }_{\mathrm{a} 1}$ was around 1 . As we did not see 
the activity lessen at the lowest $\mathrm{pHs}$ in Fig 3, we deduce that $\mathrm{pK}_{\mathrm{a} 1}$ is below 1, and the shift in $\mathrm{pK}_{\mathrm{a} 1}$ induced by cellulose binding would thus be at least $2 \mathrm{pH}$ units.

\section{Conclusions}

One practical implication of this work is that $\mathrm{pH}$ profiles of cellulases acting on substrate analogs may differ considerably from the profile on insoluble substrate (see e.g. Fig. 4). It follows the dependence on $\mathrm{pH}$ of the activity is not only an intrinsic enzyme property, but also the result of specific enzyme-substrate interactions. This, in turn, means that (convenient) experiments with soluble substrate can be inapt for evaluation of $\mathrm{pH}$-effects on cellulose hydrolysis. In addition, we found smaller but significant differences in $\mathrm{pH}$ profiles when the substrate concentration was changed, and this calls for further caution in the general use of simple model experiments in assessments of $\mathrm{pH}$ effects on cellulases acting on insoluble substrate.

Earlier work on Cel7A has revealed small differences in $\mathrm{pH}$ profiles made with different soluble substrate analogs (Becker et al., 2001), and this has been attributed to interactions in the Michaelis complex that shifts the $\mathrm{pK}_{\mathrm{a}}$ of key catalytic residues (Bu et al., 2013). Such shifts due to local interactions of catalytic residues (including larger shifts than those observed here) are common in enzymes (Harris \& Turner, 2002) and undoubtedly also relevant for the $\mathrm{pH}$ profiles observed in this work. However, the results on real cellulose, particularly the strong downshift in the $\mathrm{pK}_{\mathrm{a}}$ of the nucleophile in Cel7A does not appear to be fully explained by ligand binding. Thus, a thorough computational analysis of single-residue $\mathrm{pK}_{\mathrm{a}}$-values in both apo-Cel7A and the Michaelis complex did not find this shift, but instead reported an upward change of about $1 \mathrm{pH}$ unit (Bu et al.,

This article is protected by copyright. All rights reserved. 
2013). This difference obviously spurs interest in other mechanisms than ligand interactions, and the most obvious alternative is effects associated with the surface properties of the insoluble substrate. Such effects are captured neither by simulations of an (aqueous) Michaelis complex, nor in experiments with soluble substrates, and they may occur for example due to enzyme-surface interactions or local $\mathrm{pH}$ gradients near the surface. $\mathrm{pH}$ gradients at interfaces are well known (Yamaguchi, Bhattacharyya, \& Tahara, 2011), and have been shown to modify interfacial enzyme activity (McLaren \& Estermann, 1957), but appraisal of this for cellulases awaits more direct experimental or computational evidence. Regardless of underlying mechanisms, however, the nucleophile of Cel7A appears to become a very strong acid in Michaelis complexes formed on the surface of insoluble cellulose, and this is associated with an unusual ability of this enzyme to retain activity at very low $\mathrm{pH}$ values.

\section{Acknowledgements}

This study was funded by the Novo Nordisk Foundation, Innovation Fund Denmark [Grant number: 5150-00020B to P.W.] and Carlsberg Foundation [Grant number: 201301-0208].

The authors declare the following conflicts of interest: Kim Borch and Trine Holst Sørensen works for Novozymes A/S, a major manufacturer of industrial enzymes.

\section{References}

Alasepp, K., Borch, K., Cruys-Bagger, N., Badino, S., Jensen, K., Sorensen, T. H., . . . Westh, P. (2014). In Situ Stability of Substrate-Associated Cellulases Studied by DSC. Langmuir, 30(24), 7134-7142. doi:10.1021/la500161e

This article is protected by copyright. All rights reserved. 
Alberty, R. A., \& Bloomfield, V. (1963). Multiple Intermediates in Steady State Enzyme Kinetics V. Effect of $\mathrm{pH}$ on the rate of a simple enzymatic reaction. Journal of Biological Chemistry, 238(8), 2804-2810.

Andersen, M., Kari, J., Borch, K., \& Westh, P. (2018). Michaelis-Menten equation for degradation of insoluble substrate. Mathematical biosciences, 296, 93-97.

Badino, S. F., Kari, J., Christensen, S. J., Borch, K., \& Westh, P. (2017). Direct kinetic comparison of the two cellobiohydrolases Cel6A and Cel7A from Hypocrea jecorina. Biochimica et Biophysica Acta (BBA)-Proteins and Proteomics, 1865(12), 1739-1745.

Bansal, P., Hall, M., Realff, M. J., Lee, J. H., \& Bommarius, A. S. (2009). Modeling cellulase kinetics on lignocellulosic substrates. Biotechnology Advances, 27(6), 833-848. doi:10.1016/j.biotechadv.2009.06.005

Becker, D., Braet, C., Brumer, H., Claeyssens, M., Divne, C., Fagerstrom, B. R., . . . Wohlfahrt, G. (2001). Engineering of a glycosidase Family 7 cellobiohydrolase to more alkaline $\mathrm{pH}$ optimum: the $\mathrm{pH}$ behaviour of Trichoderma reesei Cel7A and its E223S/A224H/L225V/T226A/D262G mutant. Biochemical Journal, 356, 19-30. doi:10.1042/0264-6021:3560019

Boer, H., \& Koivula, A. (2003). The relationship between thermal stability and pH optimum studied with wild-type and mutant Trichoderma reesei cellobiohydrolase Cel7A. European Journal of Biochemistry, 270(5), 841-848. doi:10.1046/j.1432-1033.2003.03431.x

Borch, K., Jensen, K., Krogh, K., Mcbrayer, B., Westh, P., Kari, J., . . X Xu, H. (2014).

Borisova, A. S., Eneyskaya, E. V., Bobrov, K. S., Jana, S., Logachev, A., Polev, D. E., . . Sandgren, M. (2015). Sequencing, biochemical characterization, crystal structure and molecular dynamics of cellobiohydrolase Cel7A from Geotrichum candidum 3C. The FEBS journal, 282(23), 4515-4537. doi:10.1111/febs.13509

Borisova, A. S., Eneyskaya, E. V., Jana, S., Badino, S. F., Kari, J., Amore, A., . . Himmel, M. E. (2018). Correlation of structure, function and protein dynamics in GH7 cellobiohydrolases from Trichoderma atroviride, $T$. reesei and T. harzianum. Biotechnology for biofuels, 11(1), 5. doi:10.1186/s13068-017-1006-7

Bu, L. T., Crowley, M. F., Himmel, M. E., \& Beckham, G. T. (2013). Computational Investigation of the $\mathrm{pH}$ Dependence of Loop Flexibility and Catalytic Function in Glycoside Hydrolases. Journal of Biological Chemistry, 288(17), 12175-12186. doi:10.1074/jbc.M113.462465

Bu, L. T., Nimlos, M. R., Shirts, M. R., Stahlberg, J., Himmel, M. E., Crowley, M. F., \& Beckham, G. T. (2012). Product Binding Varies Dramatically between Processive

This article is protected by copyright. All rights reserved. 
and Nonprocessive Cellulase Enzymes. Journal of Biological Chemistry, 287(29), 24807-24813. doi:10.1074/jbc.M112.365510

Cockburn, D. W., Vandenende, C., \& Clarke, A. J. (2010). Modulating the pH-Activity Profile of Cellulase by Substitution: Replacing the General Base Catalyst Aspartate with Cysteinesulfinate in Cellulase A from Cellulomonas fimi. Biochemistry, 49(9), 2042-2050. doi:10.1021/bi1000596

Colussi, F., Garcia, W., Rosseto, F. R., de Mello, B. L., de Oliveira Neto, M., \& Polikarpov, I. (2012). Effect of pH and temperature on the global compactness, structure, and activity of cellobiohydrolase Cel7A from Trichoderma harzianum. European Biophysics Journal, 41(1), 89-98. doi:10.1007/s00249-011-0762-8

Divne, C., Ståhlberg, J., Teeri, T. T., \& Jones, T. A. (1998). High-resolution crystal structures reveal how a cellulose chain is bound in the $50 \AA$ long tunnel of cellobiohydrolase I from Trichoderma reesei. Journal of molecular biology, 275(2), 309-325. doi:10.1006/jmbi.1997.1437

Grassick, A., Murray, P. G., Thompson, R., Collins, C. M., Byrnes, L., Birrane, G., . . Tuohy, M. G. (2004). Three-dimensional structure of a thermostable native cellobiohydrolase, $\mathrm{CBHIB}$, and molecular characterization of the cel7 gene from the filamentous fungus, Talaromyces emersonii. European Journal of Biochemistry, 271(22), 4495-4506. doi:10.1111/j.1432-1033.2004.04409.x

Gruno, M., Väljamäe, P., Pettersson, G., \& Johansson, G. (2004). Inhibition of the Trichoderma reesei cellulases by cellobiose is strongly dependent on the nature of the substrate. Biotechnology and bioengineering, 86(5), 503-511.

Harris, T. K., \& Turner, G. J. (2002). Structural basis of perturbed pKa values of catalytic groups in enzyme active sites. IUBMB Life, 53(2), 85-98. doi:10.1080/15216540211468

Herlet, J., Kornberger, P., Roessler, B., Glanz, J., Schwarz, W. H., Liebl, W., \& Zverlov, V. V. (2017). A new method to evaluate temperature vs. pH activity profiles for biotechnological relevant enzymes. Biotechnol Biofuels, 10, 234. doi:10.1186/s13068-017-0923-9

Hobdey, S. E., Knott, B. C., Momeni, M. H., Taylor, L. E., Borisova, A. S., Podkaminer, K. K., . . Stahlberg, J. (2016). Biochemical and Structural Characterizations of Two Dictyostelium Cellobiohydrolases from the Amoebozoa Kingdom Reveal a High Level of Conservation between Distant Phylogenetic Trees of Life. Applied and Environmental Microbiology, 82(11), 3395-3409. doi:10.1128/aem.00163-16

This article is protected by copyright. All rights reserved. 
Jalak, J., \& Väljamäe, P. (2010). Mechanism of initial rapid rate retardation in cellobiohydrolase catalyzed cellulose hydrolysis. Biotechnology and bioengineering, 106(6), 871-883. doi:10.1002/bit.22779

Kari, J., Andersen, M., Borch, K., \& Westh, P. (2017). An Inverse Michaelis-Menten Approach for Interfacial Enzyme Kinetics. Acs Catalysis, 7(7), 4904-4914.

Kleywegt, G. J., Zou, J.-Y., Divne, C., Davies, G. J., Sinning, I., Ståhlberg, J., . . . Jones, T. A. (1997). The crystal structure of the catalytic core domain of endoglucanase I from Trichoderma reesei at $3.6 \AA$ resolution, and a comparison with related enzymes. Journal of molecular biology, 272(3), 383-397. doi:10.1006/jmbi.1997.1243

Knott, B. C., Momeni, M. H., Crowley, M. F., Mackenzie, L. F., Gotz, A. W., Sandgren, M., . . Beckham, G. T. (2014). The Mechanism of Cellulose Hydrolysis by a Two-Step, Retaining Cellobiohydrolase Elucidated by Structural and Transition Path Sampling Studies. Journal of the American Chemical Society, 136(1), 321-329. doi:10.1021/ja410291u

Knowles, J. R., \& Jencks, W. P. (1976). The Intrinsic PkA-Values of Functional Groups in Enzymes: Improper Deductions from the Ph-Dependence of Steady-State Parameter. CRC Critical Reviews in Biochemistry, 4(2), 165-173. doi:10.3109/10409237609105457

Lever, M. (1973). Colorimetric and fluorometric carbohydrate determination with phydroxybenzoic acid hydrazide. Biochemical medicine, 7(2), 274-281. doi:10.1016/0006-2944(73)90083-5

Linder, M., \& Teeri, T. T. (1997). The roles and function of cellulose-binding domains. Journal of biotechnology, 57(1-3), 15-28. doi:10.1016/S0168-1656(97)00087-4

Marangoni, A. G. (2003). Enzyme kinetics, a modern approach. Hoboken, New Jersey: John Wiley and Sons.

Marjamaa, K., Toth, K., Bromann, P. A., Szakacs, G., \& Kruus, K. (2013). Novel Penicillium cellulases for total hydrolysis of lignocellulosics. Enzyme and microbial technology, 52(6-7), 358-369. doi:10.1016/j.enzmictec.2013.03.003

McLaren, A., \& Estermann, E. F. (1957). Influence of pH on the activity of chymotrypsin at a solid-liquid interface. Archives of biochemistry and biophysics, 68(1), 157160. doi:10.1016/0003-9861(57)90336-3

Momeni, M. H., Payne, C. M., Hansson, H., Mikkelsen, N. E., Svedberg, J., Engstrom, A., . . Stahlberg, J. (2013). Structural, Biochemical, and Computational Characterization of the Glycoside Hydrolase Family 7 Cellobiohydrolase of the

This article is protected by copyright. All rights reserved. 
Tree-killing Fungus Heterobasidion irregulare. Journal of Biological Chemistry, 288(8), 5861-5872. doi:10.1074/jbc.M112.440891

Mosier, N., Wyman, C., Dale, B., Elander, R., Lee, Y. Y., Holtzapple, M., \& Ladisch, M. (2005). Features of promising technologies for pretreatment of lignocellulosic biomass. Bioresource technology, 96(6), 673-686. doi:10.1016/j.biortech.2004.06.025

Murphy, L., Bohlin, C., Baumann, M. J., Olsen, S. N., Sørensen, T. H., Anderson, L., .. . Westh, P. (2013). Product inhibition of five Hypocrea jecorina cellulases. Enzyme and microbial technology, 52(3), 163-169.

Ogunmolu, F. E., Jagadeesha, N. B. K., Kumar, R., Kumar, P., Gupta, D., \& Yazdani, S. S. (2017). Comparative insights into the saccharification potentials of a relatively unexplored but robust Penicillium funiculosum glycoside hydrolase 7 cellobiohydrolase. Biotechnology for Biofuels, 10. doi:10.1186/s13068-017-0752$\mathrm{x}$

Olsen, J. P., Alasepp, K., Kari, J., Cruys-Bagger, N., Borch, K., \& Westh, P. (2016). Mechanism of product inhibition for cellobiohydrolase Cel7A during hydrolysis of insoluble cellulose. Biotechnology and bioengineering, 113(6), 1178-1186.

Pace, C. N., Vajdos, F., Fee, L., Grimsley, G., \& Gray, T. (1995). How to measure and predict the molar absorption coefficient of a protein. Protein Science, 4. doi:10.1002/pro.5560041120

Payne, C. M., Resch, M. G., Chen, L. Q., Crowley, M. F., Himmel, M. E., Taylor, L. E., ... Beckham, G. T. (2013). Glycosylated linkers in multimodular lignocellulosedegrading enzymes dynamically bind to cellulose. Proceedings of the National Academy of Sciences of the United States of America, 110(36), 14646-14651. doi:10.1073/pnas.1309106110

Pellegrini, V. O., Serpa, V. I., Godoy, A. S., Camilo, C. M., Bernardes, A., Rezende, C. A., . . . Polikarpov, I. (2015). Recombinant Trichoderma harzianum endoglucanase I (Cel7B) is a highly acidic and promiscuous carbohydrate-active enzyme. Applied Microbiology and Biotechnology, 99(22), 9591-9604. doi:10.1007/s00253-0156772-1

Qin, Y., Wei, X., Song, X., \& Qu, Y. (2008). Engineering endoglucanase II from Trichoderma reesei to improve the catalytic efficiency at a higher $\mathrm{pH}$ optimum. Journal of Biotechnology, 135(2), 190-195. doi:10.1016/j.jbiotec.2008.03.016

Schiano-di-Cola, C., Røjel, N., Jensen, K., Kari, J., Sørensen, T. H., Borch, K., \& Westh, P. (2019). Systematic deletions in the cellobiohydrolase (CBH) Cel7A from the

This article is protected by copyright. All rights reserved. 
fungus Trichoderma reesei reveal flexible loops critical for CBH activity. Journal of Biological Chemistry, 294(6), 1807-1815.

Schülein, M. (1997). Enzymatic properties of cellulases from Humicola insolens. Journal of biotechnology, 57(1-3), 71-81. doi:10.1016/S0168-1656(97)00090-4

Sørensen, T. H., Cruys-Bagger, N., Windahl, M. S., Badino, S. F., Borch, K., \& Westh, P. (2015). Temperature effects on kinetic parameters and substrate affinity of Cel7A cellobiohydrolases. Journal of Biological Chemistry, jbc. M115. 658930.

Sørensen, T. H., Windahl, M. S., McBrayer, B., Kari, J., Olsen, J. P., Borch, K., \& Westh, P. (2017). Loop variants of the thermophile Rasamsonia emersonii Cel7A with improved activity against cellulose. Biotechnology and bioengineering, 114(1), 53-62. doi:10.1002/bit.26050

Taylor, C. B., Payne, C. M., Himmel, M. E., Crowley, M. F., McCabe, C., \& Beckham, G. T. (2013). Binding Site Dynamics and Aromatic-Carbohydrate Interactions in Processive and Non-Processive Family 7 Glycoside Hydrolases. Journal of Physical Chemistry B, 117(17), 4924-4933. doi:10.1021/jp401410h

Teugjas, H., \& Väljamäe, P. (2013). Product inhibition of cellulases studied with 14 Clabeled cellulose substrates. Biotechnology for biofuels, 6(1), 104.

Texier, H., Dumon, C., Neugnot-Roux, V., Maestracci, M., \& O'Donohue, M. J. (2012). Redefining XynA from Penicillium funiculosum IMI 378536 as a GH7 cellobiohydrolase. Journal of Industrial Microbiology \& Biotechnology, 39(11), 1569-1576. doi:10.1007/s10295-012-1166-1

Voutilainen, S. P., Murray, P. G., Tuohy, M. G., \& Koivula, A. (2010). Expression of Talaromyces emersonii cellobiohydrolase Cel7A in Saccharomyces cerevisiae and rational mutagenesis to improve its thermostability and activity. Protein Engineering Design \& Selection, 23(2), 69-79. doi:10.1093/protein/gzp072

Westh, P., Borch, K., Sørensen, T., Tokin, R., Kari, J., Badino, S., ... Vesterager, C. S. (2018). Thermoactivation of a cellobiohydrolase. Biotechnology and bioengineering, 115(4), 831-838.

Yamaguchi, S., Bhattacharyya, K., \& Tahara, T. (2011). Acid-Base Equilibrium at an Aqueous Interface: $\mathrm{pH}$ Spectrometry by Heterodyne-Detected Electronic Sum Frequency Generation. The Journal of Physical Chemistry C, 115(10), 4168-4173. doi:10.1021/jp1113174

Zhang, Y. H., \& Lynd, L. R. (2004). Toward an aggregated understanding of enzymatic hydrolysis of cellulose: noncomplexed cellulase systems. Biotechnology and bioengineering, 88(7), 797-824.

This article is protected by copyright. All rights reserved. 
Zou, J. Y., Kleywegt, G. J., Stahlberg, J., Driguez, H., Nerinckx, W., Claeyssens, M., . . Jones, T. A. (1999). Crystallographic evidence for substrate ring distortion and protein conformational changes during catalysis in cellobiohydrolase Cel6A from Trichoderma reesei. Structure with Folding \& Design, 7(9), 1035-1045.

\section{Tables}

Table 1: Estimated $\mathbf{p K}_{\mathrm{a}} \mathrm{s}$ at high and low $\mathbf{p N P L}$ concentrations. Parameters were derived from non-linear regression analysis using the experimental activity data for TrCel7A, ReCel7A and TrCel7B at pH 2-7, $30{ }^{\circ} \mathrm{C}$ at low and high pNPL concentration (See Supporting information, figure S4). All fits were done using equation S2 and S3 (see Supporting information). As TrCel6A has essentially no activity on pNPL, this enzyme was excluded.

\begin{tabular}{|c|c|c|c|c|}
\hline \multirow[b]{2}{*}{ Enzyme } & \multicolumn{2}{|c|}{$0.2 \mathrm{mM}$ pNPL } & \multicolumn{2}{|c|}{$9 \mathrm{mM}$ pNPL } \\
\hline & $\mathbf{p K}_{\mathrm{a} 1}$ & $\mathbf{p K}_{\mathrm{a} 2}$ & $\mathbf{p K}_{\mathrm{al}}$, & $\mathbf{p K}_{\mathrm{a} 2}$ \\
\hline TrCel7A & $2.7 \pm 0.1$ & $5.7 \pm 0.1$ & $1.6 \pm 0.1$ & $5.4 \pm 0.1$ \\
\hline ReCel7A & $2.6 \pm 0.1$ & $6.0 \pm 0.1$ & $2 \pm 0.1$ & $6.1 \pm 0.1$ \\
\hline TrCel7B & $2.6 \pm 0.1$ & $5.1 \pm 0.1$ & $2.2 \pm 0.1$ & $5.5 \pm 0.1$ \\
\hline
\end{tabular}

Table 2: Estimated $\mathbf{p K}_{\mathbf{a}} \mathrm{s}$ at $20-50{ }^{\circ} \mathrm{C}$ using high Avicel load. The acid dissociation constants were obtained from non-linear regression analysis to the experimental activity data in figure 1. All fits were done using equation S3 (see Supporting information). Fitted curves can be found in supporting figure S5.

\begin{tabular}{l|l|l|l|l}
\hline TrCel7A & ReCel7A & TrCel7B & TrCel6A \\
\hline
\end{tabular}

This article is protected by copyright. All rights reserved. 


\begin{tabular}{|c|c|c|c|c|c|c|c|c|}
\hline Temp. & $\mathbf{p K}_{\mathrm{a} 1}^{\prime}$ & $\mathbf{p K}_{\mathrm{a} 2}^{\prime}$ & $\mathbf{p K}_{\mathrm{a} 1}^{\prime}$ & $\mathbf{p K}_{\mathrm{a} 2}^{\prime}$ & $\mathbf{p K}^{\prime}{ }_{\mathrm{a} 1}$ & $\mathbf{p K}_{\mathrm{a} 2}^{\prime}$ & $\mathbf{p K}_{\mathrm{a} 1}^{\prime}$ & $\mathbf{p K}_{\mathrm{a} 2}^{\prime}$ \\
\hline $20^{\circ} \mathrm{C}$ & $\dagger$ & $6.3 \pm 0.2$ & $\dagger$ & $6.6 \pm 0.2$ & $2.0 \pm 0.1$ & $6.0 \pm 0.1$ & $1.7 \pm 0.1$ & $6.3 \pm 0.1$ \\
\hline $30^{\circ} \mathrm{C}$ & $\dagger$ & $6.7 \pm 0.1$ & $\dagger$ & $6.4 \pm 0.1$ & $2.1 \pm 0.2$ & $6.1 \pm 0.1$ & $1.8 \pm 0.1$ & $6.4 \pm 0.1$ \\
\hline $40^{\circ} \mathrm{C}$ & $\dagger$ & $7.0 \pm 0.0$ & $\dagger$ & $6.5 \pm 0.1$ & $2.5 \pm 0.1$ & $6.1 \pm 0.1$ & $1.9 \pm 0.1$ & $6.6 \pm 0.1$ \\
\hline $50^{\circ} \mathrm{C}$ & $\dagger$ & $7.5 \pm 0.2$ & $\dagger$ & $6.7 \pm 0.1$ & $\ddagger$ & $\ddagger$ & $2.4 \pm 0.1$ & $6.8 \pm 0.1$ \\
\hline
\end{tabular}

†) $\mathrm{pK}_{\mathrm{a}}$ too low to be modelled in the current range (pH 2-7). Theoretical curves and estimates of experimental errors suggest that $\mathrm{pK}_{\mathrm{a}}$ is below 1 in these cases. ‡) Enzyme was thermally unstable. Data not analyzed.

\section{Figures}

Figure 1: pH-activity profiles at different temperatures (panels A-D) and enzyme stability ( $\left.\mathbf{T}_{\mathrm{m}}\right)$ as a function of pH with (filled) and without (unfilled) substrate (Panels E-H). Specific activity at $20-70{ }^{\circ} \mathrm{C}$ using Avicel as substrate was measured between pH 2-7 with 0.5 unit interval for A) TrCel7A, B) ReCel7A, C) TrCel7B and D) TrCel6A. Enzyme concentrations were 100 nM except for TrCel7B which was 25 nM. We used 90 g/L Avicel, 1 h hydrolysis time and the data points represent averages of triplicates \pm standard deviation. The right column shows $T_{m}$ measured by nanoDSF for E) TrCel7A, F), ReCel7A G) TrCel7B and H) TrCel6A at pH between pH 2-7 with (filled squares) and without (unfilled squares) $90 \mathrm{~g} / \mathrm{L}$ Avicel. All measurements were performed with $1 \mu \mathrm{M}$ enzyme and as duplicates. The $y$-axis of $\mathrm{T}_{\mathrm{m}}$ data is fixed.

This article is protected by copyright. All rights reserved. 


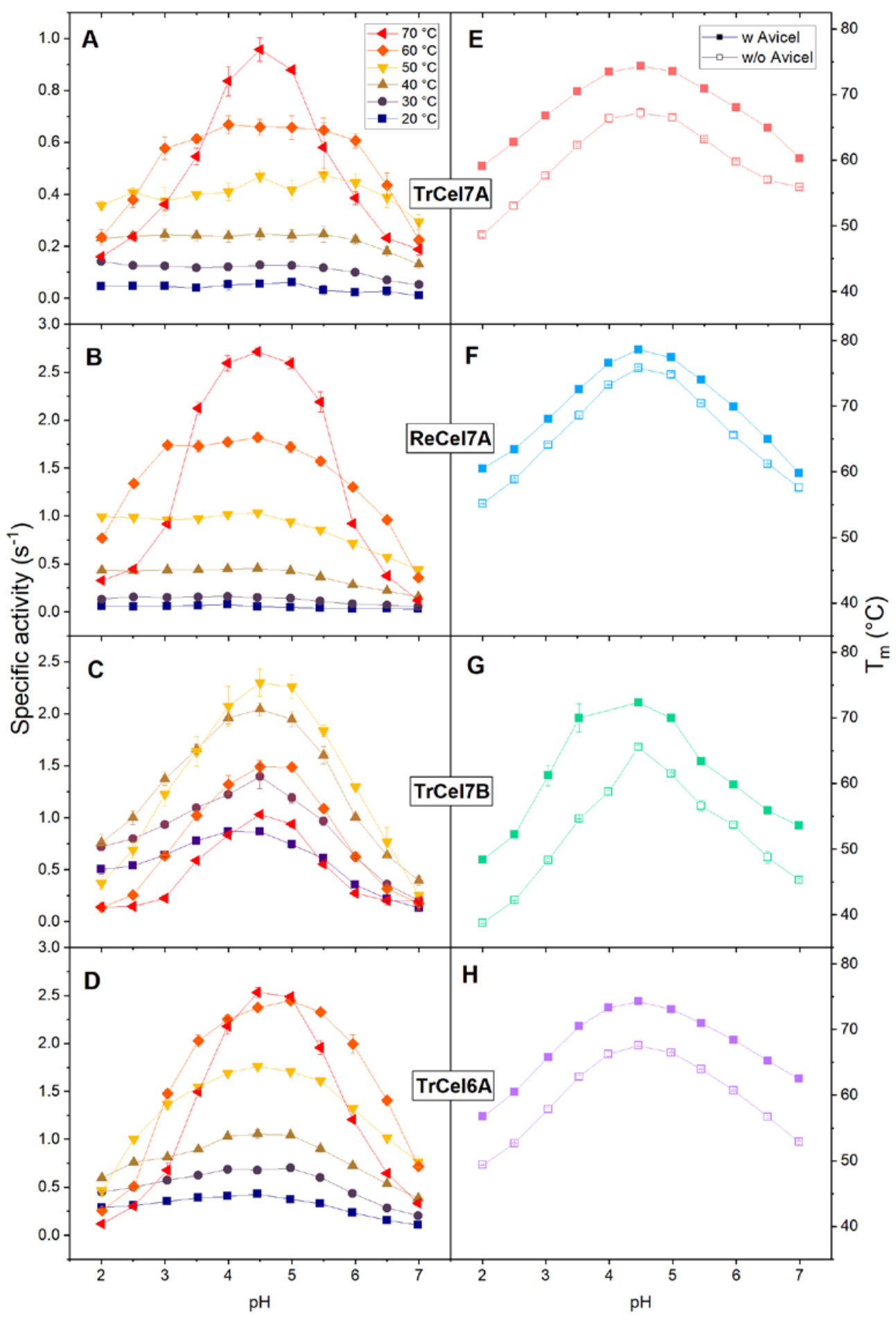

This article is protected by copyright. All rights reserved. 
Figure 2: pH dependence of activity of TrCel7A, TrCel7B and ReCel7A on high (A-C) and low (D-F) pNPL concentration. Conditions: $30^{\circ} \mathrm{C}, 15 \mathrm{~min}, 9.0 \mathrm{mM}$ pNPL (A-C) and $0.2 \mathrm{mM}$ pNPL (D-F) using $0.5 \mu \mathrm{M}$ Cel7A and 0.2 $\mu \mathrm{M}$ Cel7B. Note that the standard deviation for many of the data points were smaller than the symbol.
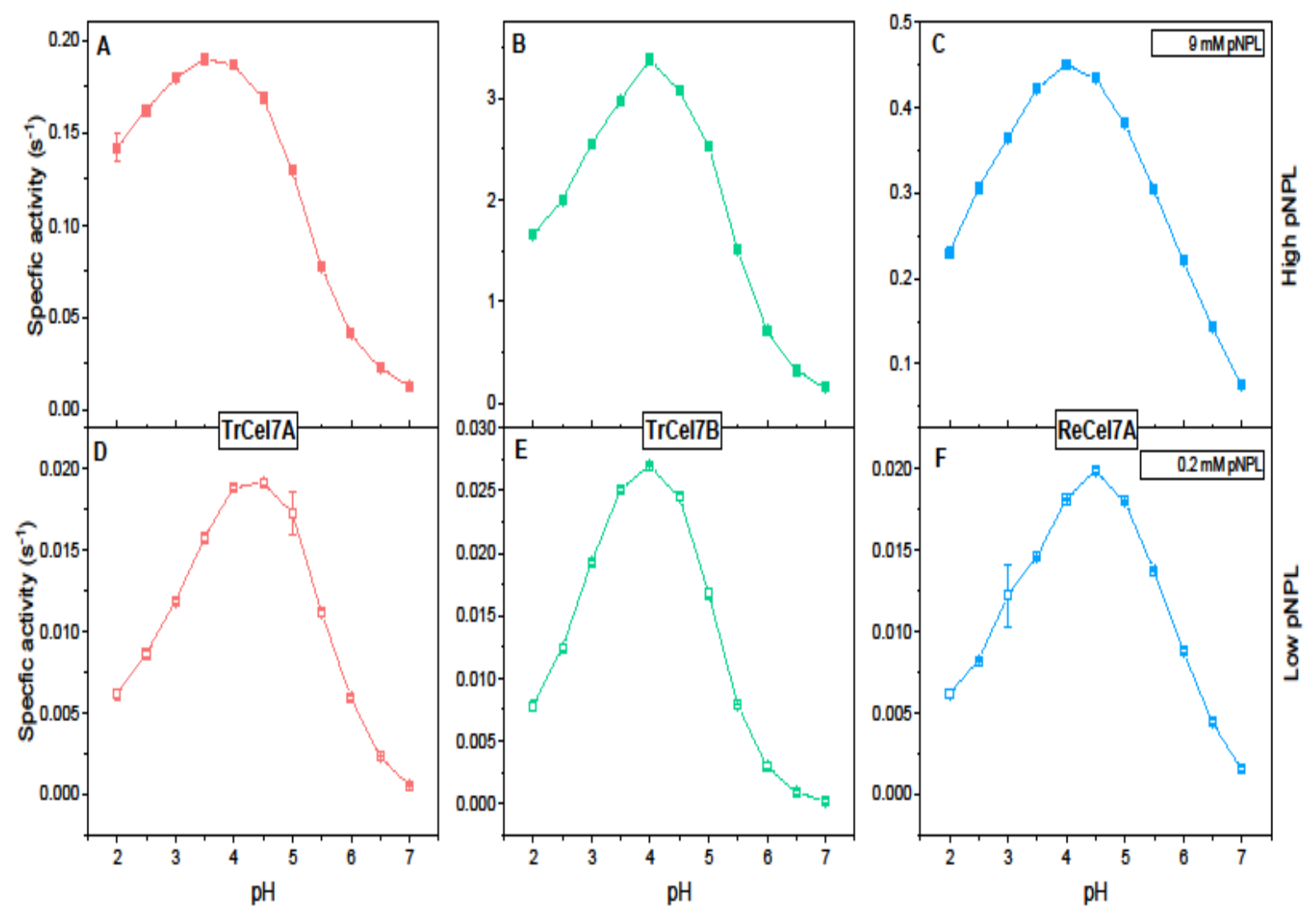

This article is protected by copyright. All rights reserved. 
Figure 3. Activity at $40{ }^{\circ} \mathrm{C}$ on $90 \mathrm{~g} / \mathrm{L}$ Avicel plotted as a function of $\mathrm{pH}$ (panel A), and structure of the enzymesubstrate complexes (panel B). To facilitate direct comparisons, activities are given at relative values with respect to the activity at $\mathrm{pH}$ 4.5. The underlying data is taken from Fig. 1.
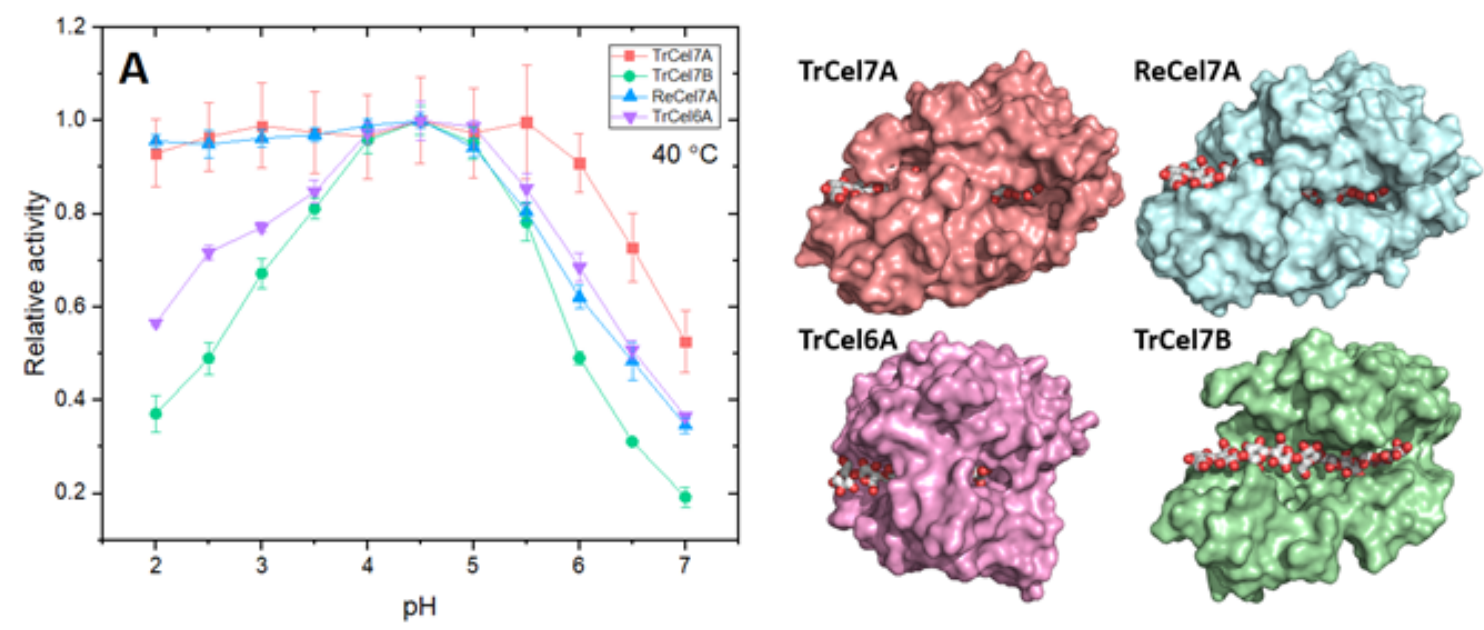

Figure 3. Relative enzyme activity on $90 \mathrm{~g} / \mathrm{L}$ Avicel as a function of $\mathrm{pH}(\mathrm{A})$, and structure of the catalytic core-substrate complexes (B).

This article is protected by copyright. All rights reserved. 
Figure 4. Relative activities for TrCel7A acting on high and low concentrations of soluble (pNPL) and insoluble (Avicel) substrate.

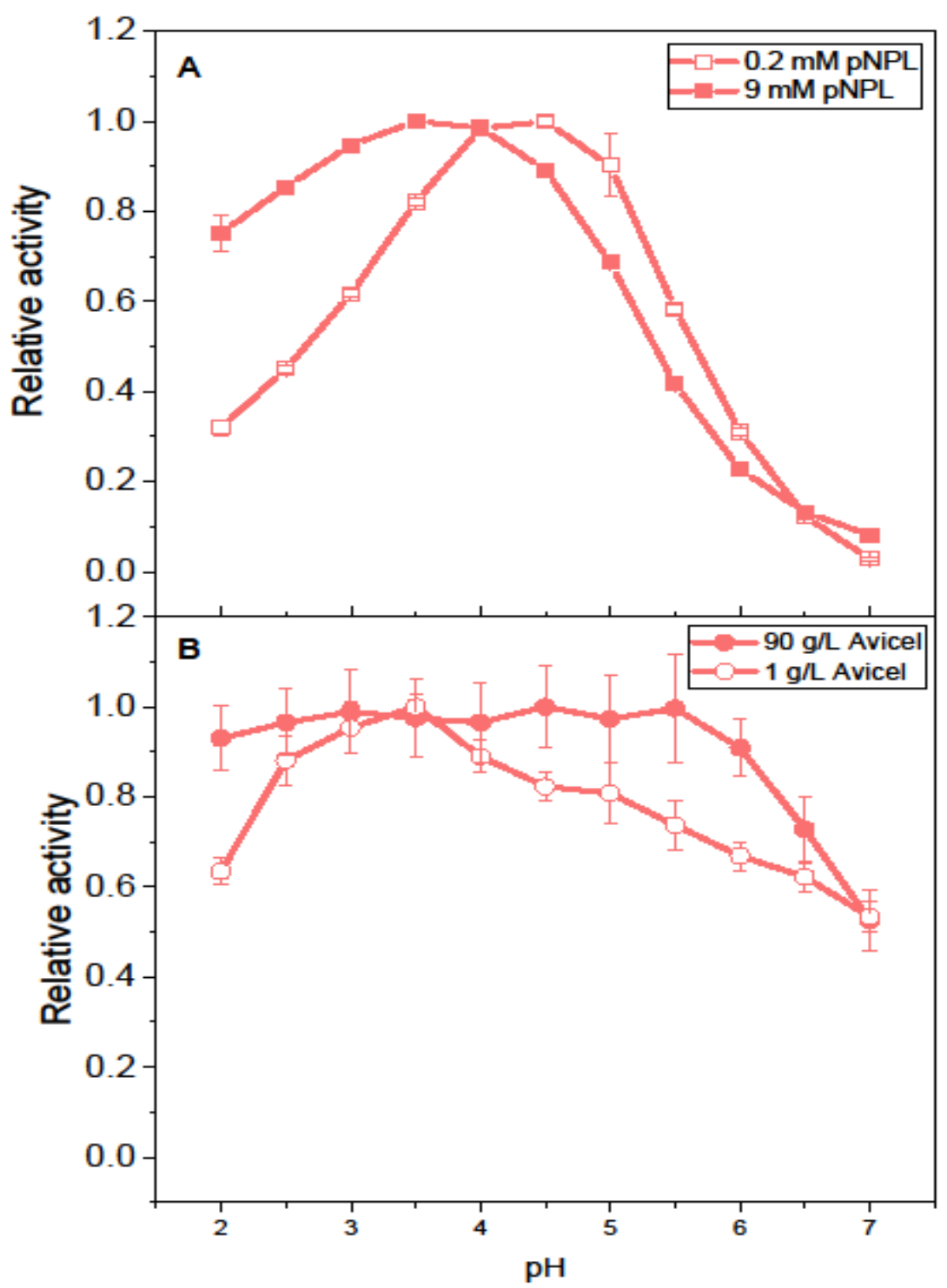

This article is protected by copyright. All rights reserved. 